Volume : 19, Nomor : 2

ISSN Online : $2613-9340$

ISSN Offline : $1412-1255$

\section{PELAKSANA PERJANJIAN LISAN SEWA \\ KAMAR KOS DI KELURAHAN TELADAN \\ BARAT, KECAMATAN MEDAN KOTA, KOTA MEDAN}

\author{
Oleh: Nurasiah Harahap, SH, M.Hum ${ }^{1}$
}

\begin{abstract}
Abstrak
Perjanjian sewa-menyewa merupakan perjanjian yang timbul dari Undang-Undang yakni diatur dalam Pasal $1548 \mathrm{~s} / \mathrm{d} 1600$ KUHPerdata. Pelaksanaan perjanjian lisan sewa kamar kos di Kelurahan Teladan Barat Kecamatan Medan Kota, Kota Medan merupakan persetujuan Konsensual. Penelitian ini bersifat deskriptif analisis yaitu untuk menyajikan gambaran tentang pelaksanaan, hambatan dan cara mengatasi hambatan dalam perjanjian lisan sewa kamar kos.

Ketentuan perjanjian sewa kamar kos yang dibuat secara lisan di Kelurahan Teladan Barat Kecamatan Medan Kota, Kota Medan, sesuai dengan ketentuan Pasal 1233 KUHPerdata. Pelaksanaan perjanjian lisan sewa kamar kos, perjanjian dianggap sah apabila ada kata sepakat mengenai kamar kos dan harga sewa maka para pihak memiliki hak dan kewajiban yang harus dilaksanakan. Tetapi dalam pelaksanaannya terdapat hambatan dan masalah.

Dapat disimpulkan bahwa pelaksanaan perjanjian lisan sewa kamar kos di Kelurahan Teladan Barat Kecamatan Medan, Kota Medan ditemukan pendapat yang berbeda dari responden dan pelaksanaan perjanjian mengenai hambatan dan masalah yaitu tidak ada kejelasan karena dibuat secara lisan dan kendala dari jumlah warga pendatang untuk pendataan bagi kepala lingkungan setempat.
\end{abstract}

Kata Kunci : Perjanjian lisan, Sewa kamar Kos, Kelurahan Teladan Barat Kecamatan Medan Kota, Kota Medan

\section{Abstract}

Lease agreements are agreements arising from the Law, which are regulated in Pasal 1548 to 1600 KUHPerdata. The implementation of the verbal agreement on room rentals in Teladan Barat, Medan City District, Medan City is a consensual agreement. This research is a descriptive analysis which is to present an overview of the implementation, barriers and how to overcome obstacles in the verbal agreement of rent a room.

The provisions of the room rental agreement made verbally in Teladan Barat Village, Medan City District, Medan City, are in accordance with Pasal 1233 KUHPerdata. Implementation of verbal agreement to rent a room is considered valid if there is an agreement on the room and the price, the parties have the rights and obligations that must be implemented. But in practice there are obstacles and problems.

It can be concluded that the implementation of verbal agreement on room rent in Teladan Barat Village, Medan District, Medan City found different opinions from respondents and the implementation of the agreement regarding obstacles and problems was no clarity because it was made verbally and the constraints of the number of migrants for data collection for the head of the village.

Keywords : Verbal agreement, room rent, Teladan Barat Village, Medan District, Medan City

\section{Pendahuluan}

\section{A. Latar Belakang}

Kebutuhan masyarakat akan tempat tinggal sangat mendesak dewasa ini. Setiap tahun mengalami peningkatan sesuai dengan pertumbuhan penduduk. Tidak semua orang mampu memiliki rumah sendiri padahal kebutuhan akan tempat untuk berteduh bagi manusia merupakan kebutuhan primer disamping sandang dan pangan.

Pertumbuhan penduduk yang sangat cepat mengakibatkan kebutuhan rumah juga semakin meningkat meningkat terutama dikotakota besar, masalah kekurangan rumah menjadi lebih parah lagi, belum lagi harga rumah dan tanah yang semakin tinggi, sehingga tidak semua orang dapat menjangkau untuk membeli rumah ataupun membangun rumah sendiri, sehingga antara orang yang satu dengan yang lainnya saling membutuhkan. Mereka saling melibatkan 
diri untuk membuat suatu perikatan yang dibutuhkannya.

Makna "perjanjian atau verbintenis mengandung pengertian suatu hubungan hukum kekayaan, harta benda antara dua orang atau lebih, yang memberikan kekuatan hak pada suatu pihak untuk memperoleh prestasi dan sekaligus mewajibkan pihak lain untuk menunaikan prestasi" ${ }^{2}$. Perjanjian merupakan sumber terpenting yang melahirkan perikatan. Perikatan paling banyak diterbitkan oleh suatu perjanjian, tetapi ada juga sumber - sumber lain yang melahirkan perikatan. Sumber - sumber lain ini "tercakup dengan nama undang undang" ${ }^{3}$. Dengan demikian ada perikatan yang lahir dari perjanjian dan ada perikatan yang lahir dari undang - undang. Eksistensi perjanjian sebagai salah satu sumber perikatan diatur pada Pasal 1233 KUHPerdata, yang berbunyi "tiap tiap perikatan dilahirkan baik karena perjanjian, baik karena undang - undang". Ketentuan tersebut dipertegas lagi dengan bunyi Pasal 1313 KUHPerdata, yang berbunyi "suatu perjanjian adalah suatu perbuatan dengan mana satu orang atau lebih mengikatkan dirinya terhadap satu orang lain atau lebih".

Perjanjian adalah "suatu perhubungan hukum mengenai harta benda antara dua pihak, dalam mana suatu pihak berjanji atau dianggap berjanji untuk melakukan sesuatu hal atau untuk tidak melakukan sesuatu hal, sedang pihak lain berhak menuntut pelaksanaan janji itu"4. "Suatu perjanjian harus memenuhi syarat sahnya perjanjian, yaitu kata sepakat, kecakapan, hal tertentu dan suatu sebab yang halal,

${ }^{2} \mathrm{M}$. Yahya Harahap, Segi - Segi Hukum Perjanjian, Alumni, Bandung, 1986, h. 6. 1979. h. 1

${ }^{3}$ R. Subekti, Hukum Perjanjian, Intermasa, Jakarta

${ }^{4}$ Wirdjono Prodjodikaro, Azas - Azas Hukum Perjanjian, Bale Bandung, Gumur Bandung, 1979, h. 9. sebagaimana ditentukan dalam Pasal 1320 KUHPerdata". ${ }^{5}$ Dengan dipenuhinya keempat syarat sahnya perjanjian tersebut, maka suatu perjanjian menjadi sah dan mengikat secara hukum bagi pada pihak yang membuatnya. Setiap perjanjian yang melahirkan suatu perikatan diantara kedua belah pihak yang membuat perjanjian, hal ini sebagaimana diatur dalam Pasal 1338 ayat (1) KUHPerdata yang berbunyi "semua perjanjian yang dibuat secara sah berlaku sebagai undang - undang bagi mereka yang membuatnya".

Pada "umumnya perjanjian tidak terikat kepada suatu bentuk tertentu, dapat dibuat secara lisan dan andai kata dibuat secara tertulis maka ini bersifat sebagai alat pembuktian apabila terjadi perselisihan"6. Untuk beberapa perjanjian tertentu undang - undang menentukan suatu bentuk tertentu, sehingga apabila bentuk itu tidak dituruti maka perjanjian itu tidak sah. Dengan demikian bentuk tertulis tidaklah hanya semata mata merupakan alat pembuktian saja, tetapi merupakan syarat untuk adanya perjanjian itu.

Seperti halnya dengan jual-beli dan perjanjian - perjanjian lain pada umumnya, "sewa - menyewa adalah suatu perjanjian konsensual. Artinya, ia sudah sah dan mengikat pada detik tercapainya kata sepakat mengenai unsur unsur pokoknya, yaitu barang dan harga". Pengertian sewa - menyewa itu sendiri diatur dalam Pasal 1548 KUHPerdata yang berbunyi:

Sewa menyewa adalah suatu persetujuan, dengan mana pihak yang satu mengikatkan dirinya untuk memberikan kepada pihak yang lainnya kenikmatan dari sesuatu barang, selama suatu waktu tertentu dan dengan

${ }^{5}$ Suharnoko, Hukum Perjanjian Teori dan Analisa Kasus, Kencana, Jakarta, 2004, h. 1.

${ }^{6}$ Mariam Darus Badrul Zaman, KUHPerdata Buku III Hukum Perikatan dengan Penjelasanny, Alumni, Bandung, 1996, h. 89 
pembayaran sesuatu harga, yang oleh pihak tersebut belakangan ini disanggupi pembayarannya.

Dari rumusan pengertian diatas dapat dilihat, bahwa sewa - menyewa merupakan:

1. Suatu persetujuan antara pihak yang menyewakan (pada umumnya pemilik barang) dengan pihak penyewa.

2. Pihak yang menyewa menyerahkan sesuatu barang kepada si penyewa untuk sepenuhnya dinikmati.

3. Penikmatan berlangsung untuk suatu jangka waktu tertentu dengan pembayaran sejumlah harga sewa yang tertentu pula .

Seperti diuraikan diatas bahwa maksud persetujuan sewa - menyewa adalah "penikmatan" atas suatu barang dengan jalan membayar sewa untuk suatu jangka waktu tertentu. Penikmatan inilah sebagai slah satu unsur yang ditekankan pada Pasal 1548 KUHPerdata. Penikmatan itu tidak terbatas sifatnya. Seluruh kenikmatan yang dapat dikecap dari barang yang disewa, harus "diperuntukkan" bagi si penyewa. Akan tetapi penikmatan atas seluruh barang yang disewa tidak akan menimbulkan persoalan, jika si penyewa menguasai seluruh bagian barang. Masalah penikmatan bisa menimbulkan persoalan, apabila si penyewa hanya menyewa atas sebagian barang saja. Seperti halnya penyewaan atas bagian bawah suatu rumah bertingkat atau hanya menyewa satu kamar saja tentu dalam penyewaan atas sebahagian barang, si penyewa hanya berhak menikmati bahagian yang disewanya saja, sesuai dengan identifikasi yang telah ditentukan dalam persetujuan sewa menyewa.

Sewa - menyewa terhadap benda tidak bergerak seperti rumah, Pemerintah menerbitkan
Peraturan Pemerintah No 44 Tahun 1994 tentang Penghunian Rumah oleh Bukan Pemilik. Salah satu Pasal dari Peraturan Pemerintah tersebut pada Pasal 21 mengatur tentang sewa menyewa rumah baik dengan perjanjian tertulis maupun lisan harus menetapkan batas waktu. Dengan demikian "khusus mengenai perjanjian sewa - menyewa rumah haruslah diperbuat dengan suatu batas waktu tertentu dan segala bentuk perjanjian sewa - menyewa rumah yang telah diperbuat tanpa batas waktu adalah batal demi hukum".

Mencermati hal yang demikian maka perlu adanya kepastian hukum guna memberikan perlindungan hukum kepada penyewa mengenai sewa - menyewa rumah khususnya sewa menyewa hanya untuk satu kamar dari suatu rumah yang persetujuannya dibuat secara lisan.

Berdasarkan latar belakang tersebut perlu dilakukan penelitian yang berjudul "Pelaksanaan Perjanjian Lisan Sewa Kamar kos di Kelurahan Teladan Barat Kecamatan Medan Kota, Kota Medan".

\section{B. Perumusan Masalah}

Adapun yang menjadi permasalahan dalam penelitian ini adalah:

1. Bagaimana ketentuan perjanjian sewa kamar kos yang dibuat secara tidak tertulis (lisan) di Kelurahan Teladan Barat Kecamatan Medan Kota, Kota Medan?

2. Bagaimana pelaksanaan perjanjian sewa kamar kos yang dibuat secara tidak tertulis (lisan) di Kelurahan Teladan Barat Kecamatan Medan Kota, Kota Medan?

3. Apakah ada hambatan dalam perjanjian sewa kamar kos yang dibuat secara tidak tertulis (lisan) di Kelurahan Teladan Barat Kecamatan Medan Kota, Kota Medan? 


\section{Metode Penelitian}

Jenis penelitian dalam penelitian ini adalah penelitian hukum normatif dan penelitian hukum empiris. Sifat dari penelitian ini adalah bersifat deskriptif analitis. Penelitian deskriptif dimaksudkan adalah untuk menyajikan gambaran yang lengkap mengenai hubungan antara fenomena yang diuji.

Dalam penelitian ini digunakan 2 (dua) jenis teknik pengumpulan data, yaitu:

1. Studi kepustakaan (library research), yaitu penelitian dengan melakukan penelusuran literature, dokumen - dokumen hukum dan peraturan perundang - undangan yang berkaitan dengan masalah yang diteliti (studi dokumen).

2. Studi lapangan (field research), yaitu penelitian yang dilakukan dengan mengambil data langsung dari lapangan dengan menggunakan metode wawancara dan kuisioner.

Lokasi dalam penelitian ini adalah Kelurahan Teladan Barat Kecamatan Medan Kota, Kota Medan. Populasi penelitian ini adalah kamar kos yang berada di Jl. Sempurna No. 44a dan No. 44; Jl. Sederhana No. 2; Jl. SM Raja Gang Mesjid No. 6, Gang Perhubungan No. 12, Gang Batu Cuci No. 184, Gang Pulau Harapan No. 31 dan Gang Kemuning; Jl. Turi No. 37, Gang SMA UISU Pagar Hitam No. 3 dan No. 07; Jl. Teladan No. 2; Jl. Rela No. 61; Kelurahan Teladan Barat Kecamatan Medan Kota. Sementara itu pengambilan sampel dilakukan dengan teknik random sampling.

Setelah data terkumpul maka langkah yang penting adalah pengolahan data dan analisis data. Pengolahan data hasil pengumpulan data di lapangan dilakukan dengan cara editing dan pembuatan tabel (tabulasi). Pengolahan data hasil penelitian selain dapat dilakukan dengan pendekatan kuantitatif juga dengan pendekatan kualitatif.

\section{Hasil Dan Penelitian}

\section{A. Ketentuan Perjanjian Sewa Kamar Kos yng Dibuat Secara Tidak Tertulis (Lisan) di Kelurahan Teladan Barat Kecamatan Medan Kota, Kota Medan.}

Perjanjian atau Verbintenis mengandung pengertian : suatu hubungan Hukum kekayaan / harta benda antara dua orang atau lebih, yang memberi kekuatan hak pada satu pihak untuk memperoleh prestasi dan sekaligus mewajibkan pada pihak lain untuk menunaikan prestasi.

Kekecualian terdapat misalnya pada natuurlijke verbintenis. Dalam hal ini perjanjian tersebut bersifat "tanpa hak memaksa". Jadi natuurlijke verbintenis adalah perjanjian tanpa mempunyai kekuatan memaksa (de verbintenis met zonder rechtsdwang). Dengan demikian, perjanjian dapat dibedakan antara :

1. Perjanjian tanpa kekuatan hukum (zonder rechtswerking). Perjanjian tanpa kekuatan hukum ialah perjanjian yang ditinjau dari segi hukum perdata tidak mempunyai "akibat hukum" (rechtsgevolg) yang mengikat. Misalnya perjanjian keagamaan, mverbal, sopan santun dan sebagainya.

2. Perjanjian yang mempunyai kekuatan hukum "tak sempurna" (onvolledige rechtswerking), seperti natuurlijke verbintenis. Ketidak sempurnaan daya hukumnya terletak pada sanksi memaksanya, yaitu atas keengganan debitur memenuhi kewajiban prestasi, kreditur tidak diberi kemampuan oleh hukum untuk 
memkasakan pemenuhan prestasi. Jadi tidak dapat dipaksakan.

3. Verbintenis yang sempurna daya kekuatan hukumnya (volledige rechtswerking). Disini, pemenuhan dapat dipaksakan kepada debitur jika dia ingkar secara sukarela melaksanakan kewjiban prestasi.Untuk itu kreditur diberi hak oleh hukum menjatuhkan sanksi melalui tuntutan eksekusi pelaksanaan dan eksekusi riel, gantu rugi (schade vergoeding) serta uang paksa (dwangsom).

Setiap prestasi harus mempunyai "nilai ekonomi". Jika setiap prestasi harus mempunyai nilai ekonomi, dengan sendirinya pretasi itu harus mempunyai nilai uang. Inilah prinsip umum yang melandasi suatu perjanjian.

Mengenai lahirnya perjanjian, sesuai dengan ketentuan Pasal 1233 KUHPerdata, perjanjian timbul karena:

1. Persetujuan (overeenkomst)

2. Dari undang - undang

Demikian halnya dengan perjanjian sewa menyewa merupakan perjanjian yang timbul dari undang - undang yakni diatur dalam Pasal 1548 s/d 1600 KUHPerdata. Pengertian sewa menyewa adalah :

"Persetujuan antara pihak yang menyewakan dengan pihak penyewa.

Pihak yang menyewakan atau pemilik menyerahkan barang yang hendak di sewa kepada pihak penyewa untuk 'dinikmati' sepenuhnya (volledige genot)."7

Dari rumusan pengertian diatas dapat dilihat, bahwa sewa menyewa merupakan :

1) Suatu persetujuan antara pihak yang menyewakan (pada umumnya pemilik barang) dengan pihak penyewa.
2) Pihak yang menyewa menyerahkan sesuatu barang kepada si penyewa untuk sepenuhnya dinikmati (volledige genot).

3) Penikmatan berlangsung untuk suatu jangka waktu tertentu dengan pembayaran sejumlah harga sewa yang tertentu pula.

Asas hukum Perdata Indonesia digunakan pula sebagai pondasi dan dasar dalam menetapkan kesepakatan pada perjanjian lisan sewa kamar kos di Kelurahan Telada Barat Kecamatan Medan Kota, Kota Medan, yaitu asas kebebasan berkontrak (asas contracts vrij heid atau party autonomis) yang mengandung pengertian bahwa, setiap orang mengadakan perjanjian apapun juga, baik yang telah diatur dalam undang - undang maupun yang belum diatur dalam undang - undang.

Itikad baik dalam Pasal 1338 ayat (2) KUHPerdata merupakan ukuran objektif untuk menilai pelaksanaan perjanjian, artinya pelaksanaan perjanjian harus berjalan sesuai dengan norma - norma kepatutan dan kesusilaan. Pelaksanaan perjanjian ialah pemenuhan hak dan kewajiban yang telah diperjanjikan oleh para pihak agar perjanjian itu mencapai tujuannya. Sehingga perjanjian itu mempunyai kekuatan mengikat dan memaksa. Perjanjian yang telah dibuat secara sah mengikat para pihak, maka perjanjian tersebut tidak boleh diatur dan dibatalkan secara sepihak.

Dalam jurnal Indonesia Law Review yang berjudul "Contract Law In A Comparative Perspective" oleh Suharnoko dikemukakan bahwa,

"As a general rule in a contract is concluded at that meeting of mind. This is the so called consensual principles which forms the basis of contract embodied in article 1320 point one the Civil Code. 
Media Komunikasi dan Informasi Hukum dan Masyarakat

This principle is also found in article 1458 the Civil Code that a sale contract is valid and binding to the contracting parties at the moment the contracting party has consent on good and price. However for the validity of certan contract it requires formality. For example, to be valid a compromise contract shall be reduced in writing. Another requirement is found in deposit contract that for the valid contract the said good shall be delivered by a bailor and be accepted to the physical possession of the bailee. ${ }^{18}$

Perjanjian sewa kamar kos yang dibuat secara tidak tertulis (lisan) di Kelurahan Teladan Barat Kecamatan Medan Kota, Kota Medan merupakan persetujuan konsensual, yaitu perjanjian dianggap sah apabila ada kata sepakat antara kedua belah pihak yang mengadakan perjanjian tersebut. Menurut Pasal 1338 KUHPerdata perjanjian ini sudah mempunyai kekuatan mengikat. Menurut M. Yahya Harahap "perjanjian sewa menyewa ini merupakan persetujuan konsensual yang bebas bentuknya. Boleh diperbuat dengan persetujuan lisan atau tertulis" ${ }^{\prime}$. Dengan demikian perjanjian sewa kamar kos yang dibuat secara tidak tertulis (lisan) di Kelurahan Teladan Barat Kecamatan Medan Kota, Kota Medan adalah dibolehkan. Hal ini sesuai dengan pendapat dari Adriaan Bedner:

"I defined such autonomy as the condition in which legal institutions, constituting a legal system, are able perform their tasks - and notably the systematic development of substantive rules and principles of law - in accordance with the procedural rules designed to guide them, without interference from outside actors based on

${ }^{8}$ Suharnoko. "Contract Law in A Comparative Perspective" Indonesia Law Review 2 Vol. 2 (Mei - Agustus 2012) : 117 - 143.

${ }^{9}$ Uzma. "Pelaksanaan atau Eksekusi Putusan Badan Arbitrase Syariah Nasional (Basyarnas) Sebagai Kewenangan Pengadilan Agama" Jurnal Hukum \& Pembangunan 44 no. 3 (Juli 2014): 222. non-legal grounds. The lack of such autonomy is a central problem in most developing countries." 10

Untuk mengetahui pendapat pihak yang menyewakan dan pihak penyewa kamar kos mengenai bentuk perjanjian sewa di Kelurahan Teladan Barat Kecamatan Medan Kota, Kota Medan, dilakukan dengan mengambil responden para pihak yang menyewakan kamar kos dan pihak penyewa kamar kos di Kelurahan Teladan Barat Kecamatan Medan Kota, Kota Medan.

Berdasarkan hasil wawancara tertulis yang disampaikan kepada para pihak yang menyewakan dan pihak penyewa kamar kos di Kelurahan Teladan Barat Kecamatan Medan Kota, Kota Medan dapat diperoleh tanggapan mengenai bentuk perjanjian sewa menyewa kamar kos sebagai berikut :

Tabel : 1

Bentuk Perjanjian Sewa Menyewa Kamar Kos

\begin{tabular}{|c|c|c|c|c|c|}
\hline No. & Lokasi Penyewaan Kamar Kos & $\begin{array}{l}\text { Jumlah } \\
\text { responden }\end{array}$ & Lisan & Tertulis & Lain-lain \\
\hline 1 & JI. Sempurna No. 53 B & 9 & 9 & - & - \\
\hline 2 & Jl. Sempurna No. 44 & 4 & 4 & - & - \\
\hline 3 & Jl. Sederhana No. 2 & 5 & 5 & - & - \\
\hline 4 & $\begin{array}{l}\text { Jl. SM Raja Gg. Perhubungan } \\
\text { No. } 12\end{array}$ & 10 & 10 & - & - \\
\hline 5 & Jl. Rela No. $61 \mathrm{M}$ & 6 & 4 & 1 & 1 \\
\hline 6 & Jl. Teladan No. 2 & 3 & 3 & - & - \\
\hline 7 & Jl. SM Raja Gg. Kemuning & 4 & 4 & - & - \\
\hline 8 & $\begin{array}{l}\text { JI. SM Raja Gg. Pulau Harapan } \\
\text { No. } 31\end{array}$ & 15 & 11 & 2 & 2 \\
\hline 9 & Jl. Turi No. 37 & 1 & 1 & - & - \\
\hline 10 & $\begin{array}{l}\text { Jl. SM Raja Gg. Batu Cuci No. } \\
184\end{array}$ & 1 & 1 & - & - \\
\hline 11 & Jl. Turi Gg. SMA UISU No. 3 & 11 & 12 & - & - \\
\hline 12 & Jl. SM Raja Gg. Mesjid No. 6 & 1 & 1 & - & - \\
\hline 13 & Jl. SM Raja Gg. Perhubungan & 11 & 11 & - & - \\
\hline \multicolumn{2}{|r|}{ Jumlah } & 81 & 75 & 3 & 3 \\
\hline
\end{tabular}

${ }^{10}$ Bedner. "Autonomy of Law in Indonesia" Recht der Werkelijkheid 37 no. 3 (2016) : 10 - 36. 
Media Komunikasi dan Informasi Hukum dan Masyarakat

\begin{tabular}{|c|l|c|c|c|c|}
\hline No. & $\begin{array}{c}\text { Lokasi yang Menyewakan } \\
\text { Kamar Kos }\end{array}$ & $\begin{array}{c}\text { Jumlah } \\
\text { responde } \\
\mathrm{n}\end{array}$ & Lisan & Tertulis & $\begin{array}{c}\text { Lain- } \\
\text { lain }\end{array}$ \\
\hline 1 & Jl. Sempurna No. 44 & 1 & 1 & - & - \\
\hline 2 & Jl. Sempurna No. 2 & 1 & 1 & - & - \\
\hline 3 & $\begin{array}{l}\text { Jl. SM Raja Gg. } \\
\text { Perhubungan No. 12 }\end{array}$ & 1 & 1 & - & - \\
\hline 4 & Jl. Teladan No. 2 & 1 & 1 & - & - \\
\hline 5 & Jl. Turi No. 37 & 1 & 1 & - & - \\
\hline 6 & $\begin{array}{l}\text { Jl. Turi Gg. SMA UISU No. } \\
3\end{array}$ & 1 & - & - & - \\
\hline
\end{tabular}

Pada sewa menyewa, barang yang menjadi objek sewa - menyewa tadi, bukan dimiliki. Tapi hanya untuk "dinikmati". Atas dasar pemikiran inilah memungkinkan terjadinya persetujuan sewa - menyewa hanya untuk sebagian saja dari suatu benda. Misalnya persetujuan sewa - menyewa hanya untuk satu kamar dari suatu rumah adalah mungkin. Karena penyewaan atas suatu kamar jelas dapat dipakai dan dinikmati si penyewa. Dengan demikian, pada sewa - menyewa "sebahagian dari suatu benda" atau barang dapat diartikan sebagai "benda".

Seperti pada contoh tadi, satu kamar dari suatu rumah dapat disebut benda dalam sewa menyewa, dan dapat dijadikan objek persetujuan sewa - menyewa. Asal benar - benar bisa dipakai dan dinikmati oleh si penyewa.

Sewa menyewa ini merupakan persetujuan "konsensual" yang bebas bentuknya. Boleh diperbuat dengan persetujuan lisan atau tertulis. Objek persetujuan sewa - menyewapun meliputi segala jenis benda, baik atas benda berwujud, tak berwujud, maupun benda bergerak dan tidak bergerak. Jadi objek sewa - menyewa benda dapat dipersewakan. Kecuali benda - benda yang berada diluar perniagaan (buiten de hande), tentu tak dapat dipersewakan. Mengenai essensial harga sewa atau uang sewa; harus ditentukan bersama antara yang menyewakan dengan si penyewa. Karena itu, besarnya uang sewa "harus tertentu" atau sesuatu yang "dapat ditentukan". Bisa ditentukan berbentuk sejumlah uang atau berupa prestasi lain. Akan tetapi, di samping penentuan besarnya uang sewa bisa dilakukan secara tegas, penetapan besar besarnya uang sewa bisa juga dilakukan "secara diam dia

Hasil penelitian pada Tabel 1 menunjukkan perjanjian sewa menyewa kamar kos yang dilakukan antara pihak penyewa dengan yang menyewakan di Kelurahan Teladan Barat Kecamatan Medan Kota, Kota Medan adalah sewa menyewa secara lisan. Karena perjanjian yang dibuat oleh para pihak merupakan suatu perjanjian konsensuil yang artinya sudah sah apabila telah ada kesepakatan mengenai unsur pokoknya yaitu kamar kos dan harga sewa. Perjanjain sewa kamar kos bertujuan untuk memberikan hak kebendaan, tapi hanya memberikan hak perseorangan terhadap si penyewa kamar kos untuk dinikmati.

\section{B. Pelaksanaan Perjanjian Sewa Kamar Kos yang Dibuat Secara Tidak Tertulis (Lisan) di Kelurahan Teladan Barat Kecamatan Medan Kota, Kota Medan.}

Sewa menyewa secara lisan merupakan hukum yang hidup dalam masyarakat, perjanjian sewa menyewa termasuk kedalam perjanjian konsensual dimana perjanjian sudah sah dan mengikat pada detik tercapainya kesepakatan mengenai unsur - unsur pokoknya. Namun oleh Undang - Undang diadakan perbedaan (dalam akibat - akibatnya) antara sewa tertulis dan sewa lisan, sebagaimana diatur dalam ketentuan Pasal 1570 KUHPerdata dan Pasal 1571 KUHPerdata. 
Perjanjian sewa menyewa secara lisan termasuk dalam perjanjian bernama, perjanjian ini adalah suatu perjanjian konsensuil artinya perjanjian ini sudah sah dan mengikat pada detik tercapainya kesepakatan mengenai unsur unsur pokoknya, yaitu barang dan harga. Mengenai semua jenis barang baik barang bergerak maupun barang tidak bergerak yang memakai waku tertentu dan tidak memakai waktu tertentu, karena waktu bukan syarat mutlak untuk perjanjian sewa menyewa secara lisan.

Jika ditinjau sebenarnya perjanjian sewa menyewa secara lisan merupakan suatu jenis perjanjian yang bebas bentuknya, artinya perjanjian tersebut dapat diperbuat baik hanya dengan ucapan tergantung kesepakatan antar pihak penyewa dan pihak menyewakan yang ingin melakukan kesepakatan perjanjian. Demikian halnya dalam praktek perdagangan

"Maka hubungan hukum perikatan / kontraktual adalah menjadi penentu sejauh mana tanggung jawab hukum para pihak. Pada prinsipnya, hubungan kontraktual tersebut tetap mengikut syarat sahnya perjanjian. Dalam praktek perdagangan, hukum kontrak dapat mengacu kepada pola yang bersifat formil maupun materil. Dalam perspektif informasi dan komunikasi, maka selain syarat materil (Pasal 1320 KUHPerdata), secara formil kesepakatan sesungguhnya terjadi karena adanya kejelasan informasi yang disampaikan oleh para pihak sebelum berkontrak, baik terhadap identitas dirinya maupun obyek barang/jasa yang diperdagangkannya (precontractual). Dengan informasi tersebut, para pihak mencapai kesepakatan untuk membuat perjanjian (making a contract) guna selanjutnya melakukan hal - hal sebagaimana yang diperjanjikan (performing)."11

Berdasarkan hal tersebut diatas maka Perjanjian Lisan Sewa Kamar Kos di Kelurahan Teladan Barat Kecamatan Medan Kota, Kota Medan, walaupun dibuat secara lisan tetapi diawal kesepakatan antara pihak penyewa dan yang menyewakan adanya kejelasan terlebih dahulu mengenai hak dan kewajiban masing masing pihak.

Asas - asas hukum perjanjian sewa menyewa secara lisan tercantum dalam Pasal 1548 Kitab Undang - Undang Hukum Perdata sewa menyewa yalah suatu persetujuan, dengan mana pihak yang satu mengikatkan dirinya untuk memberikan kepada pihak yang lainnya kenikmatan dari sesuatu barang selama suatu waktu tertentu dan dengan pembayaran sesuatu harga, yang oleh pihak tersebut belakangan itu disanggupi pembayarannya.

Terhadap syarat esensial dalam perjanjian sewa menyewa secara lisan yakni mengenai harga sewa ditentukan secara tegas dengan penetapan besarnya uang sewa menyewa harus dibayar kepada pihak yang menyewakan. Jangka waktu atau lamanya sewa dapat saja ditentukan secara jelas dalam perjanjian, atau dengan kata lain telah disetujui oleh kedua belah pihak baik penyewa maupun yang disewakan dalam setiap bulan atau tahunnya.

Perjanjian sewa kamar kos yang dilaksanakan di Kelurahan Teladan Barat Kecamatan Medan Kota, Kota Medan dari hasil wawancara tertulis yang disampaikan kepada para pihak yang menyewakan dengan pihak penyewa kamar kos dibuat dalam bentuk lisan. Hal ini diketahui, dari 81 responden, hanya 3

${ }^{11}$ Makarim. "Kerangka Kebijakan dan Reformasi Hukum Untuk Kelancaran Perdagangan Secara Elektronik (E-Commerce) di Indonesia" Jurnal Hukum \& Pembangunan 44 no. 3 (Juli 2014) : $314-337$. 
Media Komunikasi dan Informasi Hukum dan Masyarakat

yang menyatakan secara tertulis sedangkan 3 responden tidak memberikan jawaban. Dari hasil wawancara dengan pihak yang menyewakan diketahui semua responden menyatakan bahwa perjanjian sewa kamar kos dibuat secara tidak tertulis (lisan).

Pelaksanaan perjanjian sewa kamar kos yang dibuat secara tidak tertulis (lisan) di Kelurahan Teladan Barat Kecamatan Medan Kota, Kota Medan mengenai ketentuan harga sewa kamar kost, sistem pembayaran sewa kamar kos kepada pihak penyewa setelah dilakukan penelitian dapat diketahui dari hasil wawancara tertulis yang disampaikan kepada para penyewa kamar kos yang dibuat secara lisan sebagai berikut:

Tabel : 3

\section{Ketentuan Harga Sewa atau Uang Sewa}

\begin{tabular}{|c|c|c|c|c|}
\hline No. & $\begin{array}{l}\text { Lokasi Penyewaan Kamar } \\
\text { Kos }\end{array}$ & $\begin{array}{c}\text { Jumlah } \\
\text { respond } \\
\text { en }\end{array}$ & $\begin{array}{c}\text { Ditentukan } \\
\text { oleh yang } \\
\text { menyewakan }\end{array}$ & $\begin{array}{c}\text { Ditentukan } \\
\text { bersama antara } \\
\text { yang } \\
\text { menyewakan } \\
\text { dengan si } \\
\text { penyewa }\end{array}$ \\
\hline 1 & JI. Sempurna No. 53 B & 9 & 7 & 2 \\
\hline 2 & JI. Sempurna No. 44 & 4 & 4 & - \\
\hline 3 & JI. Sederhana No. 2 & 5 & 1 & 4 \\
\hline 4 & $\begin{array}{l}\text { JI. SM Raja Gg. } \\
\text { Perhubungan No. } 12\end{array}$ & 10 & 10 & - \\
\hline 5 & JI. Rela No. $61 \mathrm{M}$ & 6 & 4 & 2 \\
\hline 6 & JI. Teladan No. 2 & 3 & 3 & - \\
\hline 7 & Jl. SM Raja Gg. Kemuning & 4 & 4 & - \\
\hline 8 & $\begin{array}{l}\text { Jl. SM Raja Gg. Pulau } \\
\text { Harapan No. } 31\end{array}$ & 15 & 8 & 7 \\
\hline 9 & Jl. Turi No. 37 & 1 & 1 & - \\
\hline 10 & $\begin{array}{l}\text { JI. SM Raja Gg. Batu Cuci } \\
\text { No. } 184\end{array}$ & 1 & 1 & - \\
\hline 11 & Jl. Turi Gg. SMA UISU No. 3 & 11 & 11 & - \\
\hline 12 & JI. SM Raja Gg. Mesjid No. 6 & 1 & 1 & - \\
\hline 13 & $\begin{array}{l}\text { JI. SM Raja Gg. } \\
\text { Perhubungan }\end{array}$ & 11 & 11 & - \\
\hline & Jumlah & 81 & 74 & 15 \\
\hline
\end{tabular}

Tabel : 4

Sistem Pembayaran Sewa Kamar Kos

\begin{tabular}{|l|l|c|c|c|l|}
\hline No. & Lokasi Penyewaan Kamar Kos & $\begin{array}{c}\text { Jumlah } \\
\text { esponden }\end{array}$ & Bulanan & ahunan & $\begin{array}{l}\text { ain- } \\
\text { ain }\end{array}$ \\
\hline 1 & Sempurna No. 53 B & 9 & 8 & - & 1 \\
\hline 2 & Sempurna No. 44 & 4 & 3 & - & 1 \\
\hline 3 & Sederhana No. 2 & 5 & 5 & - & - \\
\hline 4 & . SM Raja Gg. Perhubungan No. 12 & 10 & - & 10 & - \\
\hline 5 & Rela No. 61 M & 6 & 2 & 4 & - \\
\hline 6 & . Teladan No. 2 & 3 & 3 & - & - \\
\hline 7 & SM Raja Gg. Kemuning & 4 & - & 4 & - \\
\hline 8 & . SM Raja Gg. Pulau Harapan No. 1 & 15 & 15 & - & - \\
\hline 9 & . Turi No. 37 & 1 & - & 1 & - \\
\hline 10 & . SM Raja Gg. Batu Cuci No. 184 & 1 & 1 & - & - \\
\hline 11 & . Turi Gg. SMA UISU No. 3 & 11 & 11 & - & - \\
\hline 12 & . SM Raja Gg. Mesjid No. 6 & 1 & 1 & - & - \\
\hline 13 & SM Raja Gg. Perhubungan & 11 & 11 & - & - \\
\hline & imlah & 81 & 60 & 19 & 2 \\
\hline
\end{tabular}

Tabel : 5

Bukti Pembayaran yang Diberikan Kepada Penyewa Kamar Kos

\begin{tabular}{|l|l|c|c|c|}
\hline No. & Lokasi Penyewaan Kamar Kos & $\begin{array}{l}\text { Jumlah } \\
\text { esponden }\end{array}$ & Kwitansi & Tidak Ada \\
\hline 1 & Sempurna No. 53 B & 9 & 6 & 3 \\
\hline 2 & Sempurna No. 44 & 4 & 4 & - \\
\hline 3 & . Sederhana No. 2 & 5 & - & 5 \\
\hline 4 & . SM Raja Gg. Perhubungan No. 12 & 10 & 10 & - \\
\hline 5 & . Rela No. 61 M & 6 & 6 & - \\
\hline 6 & . Teladan No. 2 & 3 & 1 & 2 \\
\hline 7 & . SM Raja Gg. Kemuning & 4 & - & 4 \\
\hline 8 & . SM Raja Gg. Pulau Harapan No. 31 & 15 & 3 & 12 \\
\hline 9 & . Turi No. 37 & 1 & 1 & - \\
\hline 10 & . SM Raja Gg. Batu Cuci No. 184 & 1 & 1 & - \\
\hline 11 & . Turi Gg. SMA UISU No. 3 & 11 & 1 & 10 \\
\hline 12 & . SM Raja Gg. Mesjid No. 6 & 1 & 1 & - \\
\hline 13 & . SM Raja Gg. Perhubungan & 11 & 11 & - \\
\hline & imlah & 81 & 45 & 36 \\
\hline
\end{tabular}

Dari 81 (delapan puluh satu) responden untuk ketentuan harga sewa atau uang sewa 74 (tujuh puluh empat) responden menyatakan bahwa harga sewa atau uang sewa ditentukan oleh pihak yang menyewakan di awal pada saat terjadi kesepakatan antara pihak yang menyewakan dengan pihak penyewa kamar kos sesuai dengan kondisi dari kamar kos tersebut karena dari hasil wawancara tertulis dengan responden mengenai besaran harga sewa bervariasi dan sistem pembayaran terhadap sewa kamar kos 60 (enam puluh) responden 
menyatakan bulanan, sedangkan 19 (sembilan belas) responden menyatakan tahunan dan 2 (dua) responden menyatakan lain - lain yakni boleh dibayar jika telah memiliki uang.

Bukti pembayaran uang sewa sebagaimana diatur dalam Pasal 1564 KUHPerdata : apabila timbul perselisihan mengenai pembayaran uang sewa yang telah disetujui bersama "secara lisan", dan sewa menyewa telah berlangsung serta kwitansi pembayaran tidak ada, dalam hal ini hakim:

1) Harus percaya pada keterangan pihak yang menyewakan, asal keterangan tersebut dibarengi dengan sumpah.

2) Atau hakim menyuruh untuk menaksir besarnya sewa kepada seorang ahli, jika hal ini diminta oleh si penyewa.

Kewajiban para pihak dalam perjanjian lisan sewa kamar kos, hasil peneitian menunjukkan kewajiban pihak penyewa adalah:

1. Membayar uang sewa sesuai dengan kesepakatan

2. Menjaga kebersihan kamar yang disewa

3. Menjaga kebersihan kamar mandi

4. Menjaga kebersihan lingkungan sekitar

5. Membuang sampah pada tempatnya

Sedangkan kewajiban pihak yang menyewakan adalah:

1. Menyediakan fasilitas

2. Menjaga keamanan

Terhadap kerusakan kamar kos yang bertanggung jawab adalah pihak penyewa. Kewajiban ini sesuai dengan Pasal 1560 KUHPerdata yakni penyewa mempunyai kewajiban memakai barang yang disewa secara patut sesuai dengan tujuan yang ditentukan dalam perjanjian.

Sedangkan risiko kebakaran yang bertanggung jawab adalah:
Tabel : 6

\section{Pihak yang Bertanggung Jawab Terhadap}

Risiko Kebakaran

\begin{tabular}{|c|c|c|c|c|c|}
\hline $\begin{array}{l}\mathbf{N} \\
\text { o. }\end{array}$ & $\begin{array}{l}\text { Lokasi Penyewaan Kamar } \\
\text { Kos }\end{array}$ & $\begin{array}{c}\text { Jumlah } \\
\text { respon } \\
\text { den }\end{array}$ & Penyewa & $\begin{array}{c}\text { Yang } \\
\text { menyewak } \\
\text { an }\end{array}$ & $\begin{array}{c}\text { Tidak } \\
\text { ada } \\
\text { diperjanji } \\
\text { kan }\end{array}$ \\
\hline 1 & JI. Sempurna No. 53 B & 9 & 1 & 3 & 5 \\
\hline 2 & Jl. Sempurna No. 44 & 4 & 1 & 3 & - \\
\hline 3 & JI. Sederhana No. 2 & 5 & 3 & 1 & 1 \\
\hline 4 & $\begin{array}{l}\text { Jl. SM Raja Gg. } \\
\text { Perhubungan No. } 12\end{array}$ & 10 & 2 & 6 & 2 \\
\hline 5 & JI. Rela No. $61 \mathrm{M}$ & 6 & 4 & 2 & - \\
\hline 6 & JI. Teladan No. 2 & 3 & - & 2 & 1 \\
\hline 7 & $\begin{array}{l}\text { Jl. SM Raja Gg. } \\
\text { Kemuning }\end{array}$ & 4 & 4 & - & - \\
\hline 8 & $\begin{array}{l}\text { JI. SM Raja Gg. Pulau } \\
\text { Harapan No. } 31\end{array}$ & 15 & 3 & 9 & 3 \\
\hline 9 & JI. Turi No. 37 & 1 & - & 1 & - \\
\hline 10 & $\begin{array}{l}\text { JI. SM Raja Gg. Batu Cuci } \\
\text { No. } 184\end{array}$ & 1 & - & - & 1 \\
\hline 11 & $\begin{array}{l}\text { JI. Turi Gg. SMA UISU } \\
\text { No. } 3\end{array}$ & 11 & 3 & 8 & - \\
\hline 12 & $\begin{array}{l}\text { JI. SM Raja Gg. Mesjid } \\
\text { No. } 6\end{array}$ & 1 & - & - & 1 \\
\hline 13 & $\begin{array}{l}\text { Jl. SM Raja Gg. } \\
\text { Perhubungan }\end{array}$ & 11 & - & 11 & - \\
\hline & Jumlah & 81 & 21 & 46 & 14 \\
\hline
\end{tabular}

Dari 81 (delapan puluh satu) responden diperoleh bahwa responden menjawab pihak yang bertanggung jawab adalah pihak yang menyewakan dan 21 (dua puluh satu)responden menjawab pihak penyewa yang bertanggung jawab sedangkan 14 (empat belas) responden tidak ada diperjanjikan atau yang menyebabkan kebakaran.

Secara umum undang - undang memberi beberapa ketentuan tentang berakhirnya sewa ialah "pengosongan" barang yang disewa. Pada dasarnya sewa - menyewa akan berakhir:

Berakhir sesuai dengan batas waktu yang ditentukan secara tertulis (pasal 1576). Lain halnya ketentuan pasal 1571. Yakni lamanya perjanjian ditentukan "tanpa tertulis". 
(1) Sewa - menyewa yang berakhir dalam waktu tertentu yang diperjanjikan secara lisan. Yaitu perjajian sewa dalam jangka waktu tertentu, tapi diperbuat secara lisan. Perjanjian seperti ini tidak berakhir tepat pada waktu yang diperjanjikan. Dia berakhir setelah adanya "pemberitahuan" dari salah satu pihak tentang kehendak mengakhiri sewa - menyewa. Dalam penghentian sewa - menyewa dengan lisan pengakhiran sewa harus memperhatikan jangka waktu "penghentian" (opzeg-gingstermijn) sesuai dengan kebiasaan setempat. Batas waktu antara penghentian dengan pengakhiran inilah yang disebut "jangka waktu penghentian".

(2) Pengakhiran sewa - menyewa; baik tertulis maupun dengan lisan yang tidak ditentukan batas waktu berakhirnya.

(3) Ketentuan khusus pengakhiran sewa.

Berakhirnya perjanjian sewa lisa kamar kos, di Kelurahan Teladan Barat, Kecamatan Medan Kota, Kota Medan dapat dilihat pada tabel berikut:

Tabel : 7

\section{Hambatan dalam Sewa Menyewa Kamar Kos}

\begin{tabular}{|c|l|c|c|c|}
\hline No. & Lokasi Penyewaan Kamar Kos & $\begin{array}{c}\text { Jumlah } \\
\text { responden }\end{array}$ & Hambatan & $\begin{array}{c}\text { Tidak } \\
\text { Ada }\end{array}$ \\
\hline 1 & Jl. Sempurna No. 53 B & 9 & 2 & 7 \\
\hline 2 & Jl. Sempurna No. 44 & 4 & - & 4 \\
\hline 3 & Jl. Sederhana No. 2 & 5 & - & 5 \\
\hline 4 & $\begin{array}{l}\text { Jl. SM Raja Gg. Perhubungan } \\
\text { No. 12 }\end{array}$ & 10 & 5 & 5 \\
\hline 5 & Jl. Rela No. 61 M & 6 & 4 & 2 \\
\hline 6 & Jl. Teladan No. 2 & 3 & - & 3 \\
\hline 7 & Jl. SM Raja Gg. Kemuning & 4 & - & 4 \\
\hline 8 & $\begin{array}{l}\text { Jl. SM Raja Gg. Pulau } \\
\text { Harapan No. 31 }\end{array}$ & 15 & 1 & 14 \\
\hline 9 & Jl. Turi No. 37 & 1 & - & 1 \\
\hline 10 & $\begin{array}{l}\text { Jl. SM Raja Gg. Batu Cuci No. } \\
184\end{array}$ & 1 & - & 1 \\
\hline 11 & Jl. Turi Gg. SMA UISU No. 3 & 11 & 6 & 5 \\
\hline 12 & Jl. SM Raja Gg. Mesjid No. 6 & 1 & - & 1 \\
\hline 13 & Jl. SM Raja Gg. Perhubungan & 11 & - & 11 \\
\hline & Jumlah & 81 & 18 & 63 \\
\hline
\end{tabular}

Tabel : 8

Masalah dalam Sewa Menyewa Kamar Kos

\begin{tabular}{|c|l|c|c|c|}
\hline $\begin{array}{c}\text { N } \\
\text { o. }\end{array}$ & Lokasi Penyewaan Kamar Kos & $\begin{array}{c}\text { Jumlah } \\
\text { responden }\end{array}$ & Masalah & Tidak Ada \\
\hline 1 & Jl. Sempurna No. 53 B & 9 & 3 & 6 \\
\hline 2 & Jl. Sempurna No. 44 & 4 & - & 4 \\
\hline 3 & Jl. Sederhana No. 2 & 5 & - & 5 \\
\hline 4 & $\begin{array}{l}\text { Jl. SM Raja Gg. Perhubungan } \\
\text { No. 12 }\end{array}$ & 10 & 1 & 9 \\
\hline 5 & Jl. Rela No. 61 M & 6 & 2 & 4 \\
\hline 6 & Jl. Teladan No. 2 & 3 & - & 3 \\
\hline 7 & Jl. SM Raja Gg. Kemuning & 4 & - & 4 \\
\hline 8 & $\begin{array}{l}\text { Jl. SM Raja Gg. Pulau } \\
\text { Harapan No. 31 }\end{array}$ & 15 & 3 & 12 \\
\hline 9 & Jl. Turi No. 37 & 1 & - & 1 \\
\hline 10 & $\begin{array}{l}\text { Jl. SM Raja Gg. Batu Cuci No. } \\
184\end{array}$ & 11 & 1 & 1 \\
\hline 11 & Jl. Turi Gg. SMA UISU No. 3 & 1 & - & 1 \\
\hline 12 & Jl. SM Raja Gg. Mesjid No. 6 & 11 & 10 & 1 \\
\hline 13 & Jl. SM Raja Gg. Perhubungan & & 20 & 61 \\
\hline & Jumlah & & \\
\hline
\end{tabular}

Hasil penelitian menunjukkan bahwa ditemukan hambatan pada fasilitas yang disediakan oleh pihak yang menyewakan kamar kos seperti tidak tersedianya keranjang sampah, kamar mandi harus dibersihkan oleh pihak penyewa dan air sering padam.

Selain hambatan tersebut diatas ditemukan juga masalah seperti suara mesin air yang mengganggu disaat istirahat, keluarga bertamu (orang tua) tidak boleh menginap, padahal hanya menjenguk saja dan terhadap ketentuan atau persyaratan yang telah disepakati secara lisan terkadang pihak yang menyewakan kamar kos lupa.

Hasil wawancara dengan salah seorang kepala lingkungan di Kelurahan Teladan Barat Kecamatan Medan Kota, Kota Medan, terdapat kendala dalam mendata penyewa kamar kos menyatakan bahwa "pemilik kamar kos tidak mau melapor kepada kepling terkait dengan identitas para penyewa kamar kos, padahal kepling sudah sosialisasi kepada pemilik kamar kos."12

${ }^{12}$ Wawancara dengan Aswandi selaku Kepala Lingkungan XI Medan pada tanggal 03 Juli 2019 pukul 15.00 WIB. 
Mengamati kendala tersebut sangat sulit untuk menentukan berapa jumlah masyarakat pendatang yang menghuni tempat kos di sekitar Kelurahan Teladan Barat Kecamatan Medan Kota, Kota Medan disebabkan pihak yang menyewakan kamar kos tidak mau melaporkan kepada kepala lingkungan setempat sehingga jika terjadi hal - hal yang tidak diinginkan sangat sulit untuk menyelesaikannya karena Kepala Lingkungan sendiri tidak mengenal warganya.

Berdasarkan hambatan dan masalah serta kendala yang ditemukan dalam penelitian ini menunjukkan bahwa pelaksanaan perjanjian lisan sewa kamar kos di Kelurahan Teladan Barat Kecamatan Medan Kota, Kota Medan terdapat masalah - masalah yang perlu di cermati oleh pihak penyewa dan pihak yang menyewakan kamar kos. Upaya untuk mengatasi hambatan tersebut akan memberikan kepastian hukum kamar kos agar perjanjian sewa kamar kos dibuat secara tertulis dan dalam perjanjian sewa kamar kos dituangkan klausula - klausula secara jelas dan rinci.

\section{Kesimpulan}

1. Ketentuan perjanjian sewa kamar kos yang dibuat secara tidak tertulis (lisan di Kelurahan Teladan Barat Kecamatan Medan Kota, Kota Medan merujuk pada peraturan perundang undangan yang mengatur perjanjian sewa menyewa yang diatur dalam Pasal 1548 s/d 1600 KUHPerdata. Namun karena perjanjian sewa kamar kos dibuat secara lisan maka selain ketentuan Pasal tersebut diatas maka itikad baik dalam Pasal 1338 ayat (2) KUHPerdata merupakan ukuran objektif untuk menilai pelaksanaan perjanjian dan perjanjian sewa kamar kos merupakan persetujuan konsensual yang diperbuat dengan persetujuan lisan.

2. Pelaksanaan perjanjian sewa kamar kos yang dibuat secara tidak tertulis (lisan) di Kelurahan Teladan Barat Kecamatan Medan Kota, Kota Medan dianggap sah apabila ada kata sepakat mengenai kamar kos dan harga sewa dan menimbulkan hak dan kewajiban bagi pihak penyewa dan pihak yang menyewakan.

3. Pelaksanaan perjanjian sewa kamar kos yang dibuat secara tidak tertulis (lisan) di Kelurahan Teladan Barat Kecamatan Medan Kota, Kota Medan ditemukan hambatan dan masalah yakni pihak penyewa tidak merasa nyaman dengan lingkungan tempat kos dan kurang didukung oleh fasilitas lain yang seharusnya diperoleh oleh pihak penyewa. Dan terdapat kendala bagi Kepala Lingkungan setempat disebabkan pihak yang menyewa kamar kos tidak melaporkan para penyewa kamar kosnya sehingga menyulitkan untuk melakukan pendataan terhadap warga sekitar lingkungan tersebut. 


\section{Daftar Pustaka}

A. Buku

M. Yahya Harahap, Segi - Segi Hukum

Perjanjian, Alumni, Bandung, 1986.

Mariam Darus Badrul Zaman, KUHPerdata Buku

III Hukum Perikatan dengan

Penjelasannya, Alumni, Bandung, 1996.

R. Subekti, Hukum Perjanjian, Intermasa, Jakarta. 1979.

Suharnoko, Hukum Perjanjian Teori dan Analisa Kasus, Kencana, Jakarta, 2004.

Wirdjono Prodjodikaro, Azas - Azas Hukum Perjanjian, Bale Bandung, Gumur Bandung, 1979.

B. Peraturan

Kitab Undang - Undang Hukum Perdata

Peraturan Pemerintah No 44 Tahun 1994 tentang Penghunian Rumah oleh Bukan Pemilik

C. Jurnal

Bedner. "Autonomy of Law in Indonesia" Recht der Werkelijkheid 37 No. 3 (2016).

Makarim. "Kerangka Kebijakan dan Reformasi

Hukum Untuk Kelancaran Perdagangan

Secara Elektronik (E-Commerce) di Indonesia" Jurnal Hukum \& Pembangunan 44 No. 3 (Juli 2014).

Suharnoko. "Contract Law in A Comparative

Perspective" Indonesia Law Review 2 Vol.

2 (Mei - Agustus 2012).

Uzma. "Pelaksanaan atau Eksekusi Putusan

Badan Arbitrase Syariah Nasional (Basyarnas) Sebagai Kewenangan Pengadilan Agama" Jurnal Hukum \& Pembangunan 44 No. 3 (Juli 2014). 